ORIGINAL ARTICLE

\title{
Maternal Outcome in Women with Preeclampsia
}

\author{
UZMA SIDDIQUE ${ }^{1}$, SYEDA KHALIDA NAEEM², BUSHRA BEGUM RAMEJO ${ }^{3}$, AESHA SADAF RIZWAN ${ }^{4}$, MONIZA \\ IMRAN ${ }^{5}$, NOORJEHAN SAHITO ${ }^{6}$ \\ ${ }^{1}$ Assistant Professor Department of Gynae \& Obs, Akhtar Saeed Medical and Dental College and Hospital, Lahore \\ ${ }^{2}$ Senior Registrar Gynae \& Obs, Makran Medical College Turbat/Teaching Hospital Kech \\ ${ }^{3}$ Assistant Professor, Incharge Unit 2, Obs \& Gynae Department, Kausar Hospital/Khairpur Medical College, Khairpur Mir's \\ ${ }^{4}$ Assistant Professor, Shahida Islam Medical College, Lodhran \\ ${ }^{5}$ Consultant Gynaecologist, PAF Hospital Mianwali \\ ${ }^{6}$ Registrar, Gynae and Obs., United Medical and Dental College, Isra University, Hyderabad \\ Correspondence to: Dr. Aesha Sadaf Rizwan, E- mail: sadaf.rizwan@yahoo.com, Cell.+923244956299
}

\begin{abstract}
Aim: To determine the maternal outcomes in women presented with severe pre-eclampsia.

Study Design: Prospective/Observational

Place and Duration: Obs \& Gynae department of Akhtar Saeed Medical and Dental College and Hospital, Lahore and Kausar hospital/Khairpur Medical College, Khairpur Mir's

Methods: Total 100 patients with ages 18 to 45 years presented with pre-eclampsia were included in this study. Patients detailed demographic including age, parity, gestational age, and body mass index were recorded after taking written consent. Patients complete blood picture was examined. Complications associated with preeclampsia were examined. Data was analyzed by SPSS 23.0.

Results: Out of 100 patients $23(23 \%)$ were ages <20 years, $42(42 \%)$ were ages 20 to 30 years, 30 (30\%) were ages 31 to 40 years and 5 (5\%) were ages above 40 years. 41 (41\%) were primigravida while $59(59 \%)$ were multigravida. Mean gestational age was $34.11 \pm 3.88$ weeks. HELLP syndrome found in $21(21 \%)$ patients, 11 (11\%) patients had eclampsia, and 16 (16\%) patients had placental abruption, coagulopathy found in 4 (4\%) patients, $3(3 \%)$ patients developed acute renal failure and $2(2 \%)$ patients were died.

Conclusion: It is concluded that pre-eclampsia is highly associated with major maternal complications such as HELLP syndrome, eclampsia, placental abruption and maternal mortality.

Keywords: Pre-eclampsia, HELLP Syndrome, Placental Abruption, Eclampsia, Mortality.
\end{abstract}

\section{INTRODUCTION}

In pregnancy, there are four major hypertensive disorders: pre-eclampsia, hypertension that is chronic, pre-eclampsia that is chronic, and gestational hypertension. Usually, preeclampsia is to blame for hypertension and proteinuria in pregnancy, especially in the first trimester of pregnancy. While these findings are most commonly observed during pregnancy's final months, some women have symptoms in the second half of their pregnancy, after delivery or in the early postpartum period. It is possible to have mild or severe preeclampsia. As a result of severe illness, patients may experience severe hypertension as well as coagulopathy and thrombocytopenia. During a prenatal laboratory evaluation, hemoglobin/hematocrit and platelet count should be determined, along with liver function, as well as fetal health and growth.[1]

All hypertensive problems impact $5-10 \%$ of pregnancies. Maternal, newborn, and fetal mortality rates are increased in hypertensive diseases. Severe hemolysis, raised liver enzymes, and low platelet syndrome are among the most common complications [2].

Symptoms of severe preeclampsia include proteinuria, hypertension, and central nervous system dysfunction, as well as hepatic inflammation and liver damage. Stroke, thrombocytopenia, oliguria, pulmonary edema, a cerebrovascular accident, and severe intrauterine growth restriction were all symptoms of this condition. To confirm the diagnosis, assess the severity of the disease, monitor its progression, and try to stabilize it, women with severe preeclampsia must be hospitalized [3].

Received on 13-02-2021

Accepted on 09-06-2021
Presbyopia is a severe form of pregnancy-related hypertension that can cause major morbidity and mortality for both mother and child. These countries' maternal and perinatal mortality rates have declined in recent decades due to better understanding of the disease process. Mortality and morbidity rates remain high in other parts of the world [4].

A generalized tonic-clonic convulsion complicates preeclampsia, which is called eclampsia. A major cause of maternal illness and mortality worldwide, even though it is rare in developed nations [5, 6]Severe preeclampsia might cause abrupt blindness due to damage to the occipital brain or retina [6].

It is one of the rare consequences associated with severe preeclampsia and eclampsia.

Preeclampsia and eclampsia are responsible for 10 15 percent of all maternal deaths worldwide, respectively. In developing nations, eclampsia is the leading cause of death, while complications from preeclampsia are more common in developed countries. When severe preeclampsia occurs, pulmonary edema is a rare but significant issue.

Preeclampsia has no recognized cause. Numerous theories have been proposed to explain its pathogenesis, including immunology, cytokines, growth hormones, endothelial damage, platelet dysfunction, and genetics [8, 9].

The safety of the mother must always come first, followed by consideration for the best possible perinatal result. Delivering a baby is the only way to treat severe preeclampsia. 


\section{MATERIALS AND METHODS}

This prospective/observational study was conducted at Obs \& Gynae Department of Akhtar Saeed Medical and Dental College and Hospital, Lahore and Kausar Hospital/Khairpur Medical College, Khairpur Mir's. Total 100 patients with ages 18 to 45 years presented with pre-eclampsia were included in this study. Pre-eclampsia was defined as systolic blood pressure $>160 \mathrm{mmHG}$ and diastolic $\mathrm{BP}>110$ $\mathrm{mmHG}$ and having significant proteinuria. Patients detailed demographic including age, parity, gestational age, and body mass index were recorded after taking written consent. Patients with cardiovascular disease, patients with chronic renal failure and patients with other abdominal surgeries were excluded from this study.

Patients complete blood picture was examined. Laboratory investigations were sent after assessment. Patients were managed as indoor patients according to unit protocols and were observed for eclampsia, abruption placentae, HELLP syndrome, Global complications such as heart failure, coagulopathy, renal and maternal mortality. In patients who developed these complications, pregnancy was terminated and the condition managed.

All the data was analyzed by SPSS 23.0. Mean \pm SD was done. Frequencies and percentages were recorded in tabulation form.

\section{RESULTS}

$23(23 \%)$ were ages $<20$ years, $42(42 \%)$ were ages 20 to 30 years, $30(30 \%)$ were ages 31 to 40 years and $5(5 \%)$ were ages above 40 years. 41 (41\%) were primigravida while $59(59 \%)$ were multigravida. Mean gestational age was $34.11 \pm 3.88$ weeks. Mean body mass index (BMI) was $21.08 \pm 1.68 \mathrm{~kg} / \mathrm{m}^{2}$. (Table 1)

Table 1: Characteristics of all the patients

\begin{tabular}{|l|l|l|}
\hline Characteristics & Frequency No. & $\%$ age \\
\hline Age (Years) & 23 & 23 \\
\hline$<20$ & 42 & 42 \\
\hline 20 to 30 & 30 & 30 \\
\hline 31 to 40 & 5 & 5 \\
\hline$>40$ & 41 & 41 \\
\hline Gravidity & 49 & 59 \\
\hline Primigravida & 59 & - \\
\hline Multigravida & $34.11 \pm 3.88$ & - \\
\hline Mean Gestational Age & $21.08 \pm 1.68$ & \\
\hline Mean BMI $(\mathrm{Kg} / \mathrm{m})$ & &
\end{tabular}

According to the complications, HELLP syndrome found in $21(21 \%)$ patients, $11(11 \%)$ patients had eclampsia, and $16(16 \%)$ patients had placental abruption, coagulopathy found in $4(4 \%)$ patients, $3(3 \%)$ patients developed acute renal failure and $2(2 \%)$ patients were died. (Table 2)

Table 2: Maternal complications among all patients

\begin{tabular}{|l|l|l|}
\hline Variables & Frequency & $\%$ age \\
\hline Complications & 21 & 21 \\
\hline HELLP & 11 & 11 \\
\hline Eclampsia & 16 & 16 \\
\hline Placental abruption & 4 & 4 \\
\hline Coagulopaty & 3 & 3 \\
\hline Acute renal failure & 2 & 2 \\
\hline Died & 2 & \\
\hline
\end{tabular}

\section{DISCUSSION}

Pre-eclampsia is a common gynecological and obstetrical disorder associated with high rate of morbidity and mortality [10]. We conducted this study to examine the major maternal complications associated with pre-eclampsia. In this regard we included 100 patients presented with preeclampsia. Majority of patients $42 \%$ were ages 20 to 30 years followed by $30 \%$ had ages 30 to 40 years. These results showed similarity to many of previous studies in which the average age of patients was 35 years $[11,12]$.

In our study we found that $41 \quad(41 \%)$ were primigravida while 59 (59\%) were multigravida. Mean gestational age was $34.11 \pm 3.88$ weeks. Mean body mass index (BMI) was $21.08 \pm 1.68 \mathrm{~kg} / \mathrm{m}^{2}$. A study conducted by $\mathrm{E}$. Same findings were presented in previous study [13]

In present study, overall complications found in 57 (57\%). Among all the complications the most frequent complication was HELLP syndrome and found in 21 (21\%) patients followed by placental abruption in 16\%, eclampsia in $11 \%$, coagulopathy in $4 \%$, and acute renal failure in $3 \%$ patients. A study conducted by Nankali A et al [10] reported that 22 cases $(6.3 \%)$ who had suffered from eclamptic seizers, $1(0.3 \%)$ patient was demonstrated to have HELLP syndrome. Placental abruption was obstetric complication in $7.7 \%$ (27 cases). Women with severe preeclampsia and the HELLP syndrome were more likely to have a cesarean delivery than women without these conditions. Similar to a prior study, the most common reason for cesarean section was unreliable fetal status. [14] According to a prior study, just 2.8 percent of preeclamptic women experienced placental abruption. In general, patients with hypertension problems during pregnancy are more likely to undergo cesarean birth. [15]

Women's understanding of PE was likewise poor in previous studies. Only 14 percent of women in a research by You et al. in the United States were able to define PE appropriately [16].

In this study we found that $2(2 \%)$ patients were died and 1 of them associated with acute renal failure and 1 had HELLP syndrome. These results were comparable to some previous studies [18-20].

\section{CONCLUSION}

Pre-eclampsia is highly associated with major maternal complications and these complications has major contribution to increase maternal and fetal mortality. We concluded from this study that HELLP syndrome was the most frequent complication followed by eclampsia, abruption and coagulopathy. The mortality rate was $1.82 \%$. Also we concluded that proper and early management can helps to reduce the morbidity and mortality.

\section{REFERENCE}

1. Petit P, Top M, Chantraine F, Brichant JF, Dewandre PY, Foidart JM. Treatment of severe preeclampsia: until when and for what risks/benefits? Rev Med Liege. 2009;64(12):620-625.

2. Hutcheon JA, Lisonkova S, Joseph KS. Epidemiology of preeclampsia and the other hypertensive disorders of pregnancy. Best Pract Res ClinObstetGynaecol 2011. 
3. Brichant G, Dewandre PY, Foidart JM, Brichant JF. Management of severe preeclampsia. ActaClin Belg. 2010;65(3):163-169.

4. Alvarez Navascues $R$, Marin R. Severe maternal complications associated with preeclampsia: an almost forgotten pathology? Nefrologia. 2001;21(6):565-573.

5. Agida ET, Adeka BI, Jibril KA. Pregnancy outcome in eclamptic at the University of Abuja Teaching Hospital, Gwagwalada, Abuja: a 3 year review. Niger $J$ ClinPract. 2010;13:394-398.

6. Swende TZ, Abwa T. Reversible blindness in fulminating preeclampsia (case report) Annals Afr Med. 2009;8(3):189191.

7. Martinez Abundis E, Angulo Vazquez J, Vargas Gonzalez A, Rodriguez Arias EA. Subcapsular hepatic hematma in severe postpartum preeclampsia. Presentation of a case. GinecolObstet Mex. 1989;57:325-328.

8. Turner JA. Diagnosis and management of preeclampsia: an update. Int J Women's Health. 2010;2:327-337. doi: 10.2147/IJWH.S8550.

9. Jantasing S, Tanawattanacharoen S. Perinatal outcome in severe preeclamptic women between 24-33 weeks gestation. J Med Assoc Thai. 2009;91(1):25-29.

10. Nankali A, Malek-KhosraviSh, Zangeneh M, Rezaei $M$, Hemati Z, Kohzadi M. Maternal complications associated with severe preeclampsia. J ObstetGynaecol India. 2013;63(2):112-115. doi:10.1007/s13224-012-0283-0

11. Kongwattanakul $\mathrm{K}$, Saksiriwuttho $\mathrm{P}$, Chaiyarach $\mathrm{S}$, Thepsuthammarat K. Incidence, characteristics, maternal complications, and perinatal outcomes associated with preeclampsia with severe features and HELLP syndrome. Int $J$ Womens Health. 2018;10:371-377

12. Abalos E, Cuesta C, Carroli G, et al. Pre-eclampsia eclampsia and adverse maternal and perinatal outcomes: a secondary analysis of the World Health Organization Multicountry Survey on Maternal and Newborn Health. BJOG. 2014;121(Suppl 1):14-24

13. Khalil G, Hameed A (2017) Preeclampsia: Pathophysiology and the Maternal-Fetal Risk. J HypertensManag 3:024

14. Yildirim G, Güngördük K, Aslan H, Gül A, Bayraktar M, Ceylan Y. Comparison of perinatal and maternal outcomes of severe preeclampsia, eclampsia, and HELLP syndrome. $J$ Turk GerGynecol Assoc. 2011;12(2):90-96.

15. Gofton EN, Capewell V, Natale R, Gratton RJ. Obstetrical intervention rates and maternal and neonatal outcomes of women with gestational hypertension. Am J Obstet Gynecol. 2001;185(4):798-803.

16. You WB, Wolf M, Bailey SC, et al. Factors associated with patient understanding of preeclampsia. Hypertens Pregnancy. 2012;31(3):341-9.

17. Gabbe SG, Niebyl JR, Simpson JL, Landon MB, Galan HL, Jauniaux ER, Driscoll DA, Berghella V, Grobman WA. Obstetrics: Normal and Problem Pregnancies E-Book. Elsevier Health Sciences. 7th Edition. 2016

18. Fondjo, L.A., Boamah, V.E., Fierti, A. et al. Knowledge of preeclampsia and its associated factors among pregnant women: a possible link to reduce related adverse outcomes. BMC Pregnancy Childbirth 19, 456 (2019 